\title{
Turkish Insulin Injection Techniques Study: Complications of Injecting Insulin Among Turkish Patients with Diabetes, Education They Received, and the Role of Health Care Professional as Assessed by Survey Questionnaire
}

\author{
Selcuk Dagdelen · Oguzhan Deyneli · Nermin Olgun • Zeynep Osar Siva • Mehmet Sargin • \\ Sükrü Hatun · Mustafa Kulaksizoglu • Ahmet Kaya • Cansu Aslan Gürlek • Laurence J. Hirsch • \\ Kenneth W. Strauss (D) on behalf of the ITQ Turkish Study Group
}

Received: May 23, 2018 / Published online: June 30, 2018

(C) The Author(s) 2018

\section{ABSTRACT}

Introduction: Using the Turkish and rest of world (ROW) Injection Technique Questionnaire (ITQ) data we address key insulin injection complications.

Methods: Summarized in first ITQ paper.

ITQ Turkey Study Group (see Appendix Table 15).

Enhanced digital features To view enhanced digital features for this article go to https://doi.org/10.6084/ m9.figshare.6552659.

\section{S. Dagdelen}

Department of Endocrinology and Metabolism, Hacettepe University School of Medicine, Hacettepe Mah., 06230 Sihhıye, Ankara, Turkey

\section{O. Deyneli}

Department of Endocrinology and Metabolism, Koc University School of Medicine, Davutpasa Cad. No: 4, 34010 Topkap1, Istanbul, Turkey

N. Olgun

Nursing Department, Faculty of Health Sciences, Hasan Kalyoncu University, Havaalanı Yolu Üzeri 8. km, Sahinbey, Gaziantep, Turkey

\section{Z. O. Siva}

Department of Endocrinology, Diabetes and Metabolism, Cerrahpasa School of Medicine, Istanbul University, Cerrahpasa Mah.

Kocamustafapasa Cad. No: 53, 34098 Fatih, Istanbul, Turkey
Results: Nearly one-third of Turkish insulin users described lesions consistent with lipohypertrophy (LH) at their injection sites and $27.4 \%$ were found to have LH by the examining nurse (using visual inspection and palpation). LH lesions in the abdomen and thigh of Turkish patients are slightly smaller than those measured in ROW but more than half of Turkish patients who have LH continue to inject into them at least daily. More than a quarter of Turkish patients have frequent unexplained hypoglycemia and nearly 2 out of 5 have glycemic variability, both of which have been linked to the presence of $\mathrm{LH}$ and the habit of injecting into it. Nearly half of Turkish injectors

\footnotetext{
M. Sargin

Faculty of Medicine, Istanbul Medeniyet University, Egitim Mah. Dr. Erkin Cad., 34722 Kadıköy, Istanbul, Turkey

S. Hatun

Department of Pediatric Endocrinology and Diabetes, Koc University School of Medicine, Davutpasa Cad. No: 4, 34010 Topkap1, Istanbul, Turkey

M. Kulaksizoglu · A. Kaya

Department of Endocrinology and Metabolism, Meram Faculty of Medicine, Necmettin Erbakan University, Yunus Emre Mah. Beysehir Cad. No: 281, 42080 Meram, Konya, Turkey
} 
report having pain on injection. Of these, just over half report having painful injections only several times a month or year (i.e., not with every injection). In Turkey the diabetes nurse has by far the major role in teaching patients how to inject. Nearly $40 \%$ of Turkish injectors get their sites checked at least annually, and a larger proportion than ROW had received recent (within the last 12 months) instruction on how to inject properly. Conclusion: Turkish patients and professionals have clearly made progress in injection technique, but there are still considerable challenges ahead which the new Turkish guidelines will help address.

Funding: BD Diabetes Care.

Keywords: Infusions; Injections; Insulin; Lipodystrophy; Lipohypertrophy; Needles; Needlestick; Subcutaneous

$\begin{array}{ll}\text { Abbreviations } \\ \text { BMI } & \text { Body mass index } \\ \text { HbA1c } & \text { Glycated hemoglobin } \\ \text { HCP } & \text { Health care professional } \\ \text { ID } & \text { Intradermal } \\ \text { IM } & \text { Intramuscular } \\ \text { ITQ } & \text { Injection Technique Questionnaire } \\ \text { IU } & \text { International unit (of insulin) } \\ \text { LH } & \text { Lipohypertrophy } \\ \text { LH+ } & \text { Patients with lipohypertrophy } \\ \text { LH- } & \text { Patients without lipohypertrophy } \\ \text { PD } & \text { Pharmacodynamics } \\ \text { PK } & \text { Pharmacokinetics } \\ \text { T1DM } & \text { Type 1 diabetes } \\ \text { T2DM } & \text { Type 2 diabetes } \\ \text { TDD } & \text { Total daily dose (of insulin) }\end{array}$

C. A. Gürlek

BD Diabetes Care, Ruzgarlibahce Mah. S.Sinan Eroglu Cad. No: 6, Akel Is Merkezi A Blok -3. Kat, Kavacik, 34805 Beykoz, Istanbul, Turkey

L. J. Hirsch

BD Diabetes Care, Franklin Lakes, NJ, USA

K. W. Strauss $(\square)$

BD Diabetes Care, POB 13, Erembodegem-Dorp 86, 9320 Erembodegem, Belgium

e-mail: kenneth.strauss@bd.com

\section{INTRODUCTION}

In a previous paper we introduced the Turkish Injection Technique Questionnaire (ITQ) survey patient population and injecting practice [1]. Based on the results, Turkish best practice recommendations were drafted and endorsed by Turkish health care professionals (HCP). We propose to continue this exposé, using the same approach, for injecting complications.

\section{METHODS}

Our previous paper [1] described the methods, materials, centers, and patients who participated in the study.

\section{Ethical Considerations}

No participant-identifying information was made available to the sponsor and participants were informed that their care would not be affected in any way by their participation. They were not put at risk in any way by the study and were not paid to participate. Ethics committee approval was therefore not generally required but was obtained whenever specifically requested by a center and/or by local regulations. All 56 participating centers from 29 cities in Turkey (as in the rest of world, ROW) did so willingly and without financial incentive.

\section{RESULTS}

\section{Lipohypertrophy}

Patients were asked: Do you have any swelling or lumps under the skin at your usual injection sites that have been there for some time (weeks, months, or years)? Table 1 gives the results for both the patients' answers and the nurses' examination of all patient injection sites. Turkish results are given beside ROW. The latter constitute the values from the 41 other ITQ participating countries combined (excluding Turkey). Percentages of lipohypertrophy (LH) in 
Table 1 Lipohypertrophy in Turkey vs ROW

\begin{tabular}{lll}
\hline & $\begin{array}{l}\text { \% Turkey } \\
N=1364\end{array}$ & $\begin{array}{l}\text { \% ROW } \\
\text { N }=7657\end{array}$ \\
\hline $\begin{array}{lll}\text { Presence of lypohypertrophy as } \\
\text { per patient report }\end{array}$ & 31.2 & 29.0 \\
$\begin{array}{l}\text { Presence of lypohypertrophy as } \\
\text { per nurse examination }\end{array}$ & 27.4 & 31.5 \\
\hline
\end{tabular}

Rest of world (ROW) constitutes the values from the 41 other ITQ participating countries combined (excluding Turkey)

Turkey were lower than in ROW $(27.4 \%$ vs $31.5 \%$, respectively).

Nurses examined each of the patient's injection sites both visually and by palpation and reported any LH (Table 2). When nurses found LH they were asked to measure the lesions along their longest dimension in millimeters. Table 3 shows that LH size in Turkish patients was on average slightly lower in the abdomen and thigh and almost the same in the arm. Whenever nurses found LH they asked the patient if they were still injecting into it and $58.8 \%$ of Turkish patients said yes. They were then asked how often they did so (Table 4). Patients who injected into LH were also asked why they did so (Table 5). More than half of

Table 2 Nurse-confirmed lipohypertrophy in Turkish and ROW patients

\begin{tabular}{llll}
\hline Site & Exam type & $\begin{array}{c}\text { \% Turkey } \\
\boldsymbol{N}=\mathbf{1 2 5 9}\end{array}$ & $\begin{array}{l}\text { \% ROW } \\
\boldsymbol{N}=\mathbf{6 3 0 6}\end{array}$ \\
\hline Abdomen & Visual & 12.9 & 18.2 \\
& Palpation & 14.2 & 22.6 \\
\multirow{3}{*}{ Thigh } & Visual & 6.9 & 10.6 \\
& Palpation & 8.1 & 12.1 \\
\multirow{2}{*}{ Buttocks } & Visual & 0.8 & 2.3 \\
& Palpation & 1.4 & 3.2 \\
\multirow{3}{*}{ Arm } & Visual & 11.8 & 10.9 \\
& Palpation & 14.4 & 13.0 \\
\hline
\end{tabular}

Table 3 Size of nurse-measured lipohypertrophy (LH) in Turkish $(N=384)$ and ROW $(N=1816)$ patients

\begin{tabular}{lllcc}
\hline Size $^{\text {a }}$ & $\begin{array}{l}\text { Turkey } \\
(\mathbf{m e a n} \\
\mathbf{m m})\end{array}$ & $\begin{array}{l}\text { ROW } \\
(\mathbf{m e a n} \\
\mathbf{m m})\end{array}$ & $\boldsymbol{N}$ Turkey & $\boldsymbol{N}$ ROW \\
\hline $\begin{array}{c}\text { Abdominal } \\
\text { LH }\end{array}$ & 36.5 & 45.5 & 154 & 1166 \\
Thigh LH & 32.3 & 43.9 & 83 & 404 \\
Arm LH & 35.5 & 35.9 & 147 & 246 \\
\hline
\end{tabular}

a Size was measured as the longest dimension (usually the diameter) of the largest LH lesion present in the stated anatomic site of injection

Table 4 Frequency of injection into LH in Turkish and ROW patients

\begin{tabular}{lll}
\hline Frequency & $\begin{array}{l}\text { \% Turkey } \\
\boldsymbol{N}=\mathbf{2 7 6}\end{array}$ & $\begin{array}{l}\text { \% ROW } \\
\boldsymbol{N}=\mathbf{1 6 8 8}\end{array}$ \\
\hline Every injection & 14.5 & 17.1 \\
Frequently (daily) & 49.3 & 37.9 \\
Occasionally (weekly) & 31.5 & 30.2 \\
Seldom (monthly) & 4.7 & 14.9 \\
\hline
\end{tabular}

Table 5 Reasons patients report injecting into $\mathrm{LH}$ in Turkish and ROW patients

\begin{tabular}{lll}
\hline Reason & $\begin{array}{l}\text { \% Turkey } \\
\boldsymbol{N}=\mathbf{3 4 5}\end{array}$ & $\begin{array}{l}\text { \% ROW } \\
\boldsymbol{N}=\mathbf{1 6 0 2}\end{array}$ \\
\hline It's convenient & 18.0 & 11.6 \\
It's less painful & 23.8 & 17.4 \\
Just a habit & 31.9 & 31.5 \\
Don't know & 26.4 & 28.3 \\
\hline
\end{tabular}

Turkish patients answered "Don't know" to that question.

The worldwide ITQ data [2, 3] showed a strong association between the presence of $\mathrm{LH}$ and the total daily dose (TDD) of insulin. Over 10 international units (IU) of insulin on average was consumed in persons with lipohypertrophy 
(LH+) vs persons without lipohypertrophy (LH-). In type 2 diabetes (T2DM) patients, this average TDD difference is $13.5 \mathrm{IU}$. In type 1 diabetes (T1DM) patients, the average TDD difference is $5.4 \mathrm{IU}$. The presence of $\mathrm{LH}$ is associated with higher glycated hemoglobin (HbA1c) values, an average difference of 0.55 . In Turkey the $\mathrm{LH}+$ population had an average TDD of 59.2 IU while the LH - group averaged 52.2 IU, a $7.0 \mathrm{IU}$ spread $(p<0.01)$. In Turkish T1DM patients the difference in TDD between $\mathrm{LH}+$ and LH - patients was only $0.8 \mathrm{IU}$ (higher in $\mathrm{LH}+$ ) but this did not achieve statistical significance $(p=0.766)$. However in T2DM the difference was striking; TDD was 13.2 IU higher in $\mathrm{LH}+$ patients than in LH- $(p<0.001)$. There was also a highly significant difference in HbA1c between LH+ and LH - subjects, 9.61 vs 8.85 , respectively $(p<0.001)$.

LH is associated with not rotating injection sites properly, injecting into small areas rather than broadly spreading out injections, using insulin for many years, and reusing needles. These associations are not necessarily causative of LH, but they emerge in so many studies that their role in LH formation is now widely accepted.

Our definitions of "hypoglycemia", "frequent unexplained hypoglycemia", and "glycemic variability" have been reported in previous studies $[3,4]$. In the ITQ nurses reviewed the blood glucose meter results and medical records of each subject to determine who qualified for the three aforementioned complications. About a quarter of Turkish injectors had frequent unexplained hypoglycemia and about $40 \%$ had glucose variability (Table 6). In Turkish patients with these complications, LH was more common. Table 7 gives results for lipoatrophy.

\section{Rotation of Injection Sites}

Patients who give their injections a minimum of $1 \mathrm{~cm}$ from previous ones are said to rotate correctly. Such patients, according to worldwide ITQ results, have less glycemic variability, fewer hypo- and hyperglycemic episodes, and less LH [3]. They also have lower HbA1c values and use
Table 6 Frequency of unexplained hypoglycemia and glycemic variability in Turkish and ROW patients

\begin{tabular}{|c|c|c|c|c|}
\hline & \% Turkey & \% ROW & $N$ Turkey & $N$ ROW \\
\hline \multicolumn{5}{|c|}{ Frequent unexplained hypoglycemia ${ }^{a}$} \\
\hline Yes & 25.2 & 18.3 & 341 & 1239 \\
\hline No & 74.8 & 81.7 & 1011 & 5547 \\
\hline \multicolumn{5}{|c|}{ Glycemic variability ${ }^{b}$} \\
\hline Yes & 38.0 & 34.8 & 513 & 2359 \\
\hline No & 62.0 & 65.2 & 836 & 4415 \\
\hline
\end{tabular}

a Hypoglycemia is defined as the occurrence of at least one symptom of low sugar (e.g., palpitations, tiredness, sweating, strong hunger, dizziness, tremor) and a confirmed blood glucose meter reading $\leq 60 \mathrm{mg} / \mathrm{dL}$ $(3.3 \mathrm{mM} / \mathrm{L})$. Frequent unexplained hypoglycemia is defined as hypoglycemia occurring one or more times weekly in the absence of a definable precipitating event such as a change in medication, diet, or activity

b Glycemic variability is the presence of blood glucose oscillations from less than $60 \mathrm{mg} / \mathrm{dL}(3.3 \mathrm{mM} / \mathrm{L})$ to more than $250 \mathrm{mg} / \mathrm{dL}(13.9 \mathrm{mM} / \mathrm{L})$ at least three times a week in an unpredictable and unexplained fashion and evidence of such a pattern for at least the previous 6 months

Table 7 Nurse-reported lipoatrophy and redness in Turkish and ROW patients

\begin{tabular}{llll}
\hline Site & Finding & $\begin{array}{l}\text { \% Turkey } \\
\boldsymbol{N}=\mathbf{1 2 5 9}\end{array}$ & $\begin{array}{l}\text { \% ROW } \\
\boldsymbol{N}=\mathbf{7 5 6 5}\end{array}$ \\
\hline Abdomen & Lipoatrophy & 0.6 & 0.6 \\
& Redness & 4.8 & 3.3 \\
\multirow{3}{*}{ Thigh } & Lipoatrophy & 0.4 & 0.5 \\
& Redness & 5.0 & 2.8 \\
\multirow{2}{*}{ Buttocks } & Lipoatrophy & 0.0 & 0.2 \\
& Redness & 0.2 & 0.4 \\
\multirow{3}{*}{ Arm } & Lipoatrophy & 0.5 & 0.4 \\
& Redness & 7.6 & 3.6 \\
\hline
\end{tabular}

less insulin (lower TDD) than patients who do not rotate correctly, again related to the presence of LH. We found that $74.4 \%$ of Turkish injectors rotated their sites correctly (Table 8). 
Table 8 Frequency of correct rotation: Turkey vs ROW

\begin{tabular}{lll}
\hline & $\begin{array}{l}\text { Turkey } \\
\boldsymbol{N}=\mathbf{1 2 6 3}\end{array}$ & $\begin{array}{l}\text { ROW } \\
\boldsymbol{N}=\mathbf{6 7 3 0}\end{array}$ \\
\hline Practice correct rotation $^{\mathrm{a}}$ & 74.4 & 69.9 \\
\hline
\end{tabular}

a Correct rotation is defined as always injecting at least $1 \mathrm{~cm}$ from previous injection(s)

\section{Bleeding, Bruising, Pain, and Leakage}

Bruising or bleeding at injection sites is commonly reported, a finding that is worrying to patients but is seldom of clinical importance. In our survey $52.0 \%$ of Turkish injectors reported these findings; however, only $1.9 \%$ said it occurred "always", $22.7 \%$ reported it happened "often" (several times a week), but the majority, $53.2 \%$, said it occurred only "sometimes" (several times a month). Nearly a quarter (22.2\%) said that they saw it "almost never" (several times a year).

Approximately half of Turkish patients have pain on injection, but as with bruising, this occurred rarely. The same held for insulin leaking out of the skin at injection sites. Onethird reported leakage, but, of those who did, nearly three quarters said it was rare.

Table 9 shows who gave patients their injection training. This is usually done by diabetes nurses in Turkey. This may be because

Table 9 Professional who gave patient injection training

\begin{tabular}{lll}
\hline Injection instructor & $\begin{array}{l}\text { \% Turkey } \\
\boldsymbol{N}=\mathbf{1 3 5 9}\end{array}$ & $\begin{array}{l}\text { \% ROW } \\
\boldsymbol{N}=\mathbf{8 0 8 1}\end{array}$ \\
\hline General nurse & 16.1 & 24.0 \\
Diabetes nurse & 70.1 & 42.8 \\
Diabetes educator & 6.0 & 13.3 \\
Doctor (general practitioner) & 0.9 & 5.8 \\
Doctor (diabetes specialist) & 4.2 & 10.9 \\
Pharmacist & 1.8 & 2.1 \\
Representative of the pen/needle \\
manufacturer
\end{tabular}

Table 10 Frequency with which injection sites are checked

\begin{tabular}{lll}
\hline Frequency & $\begin{array}{l}\text { \% Turkey } \\
\boldsymbol{N}=\mathbf{1 2 0 4}\end{array}$ & $\begin{array}{l}\text { \% ROW } \\
\mathbf{N 1 1 , 3 0 1}\end{array}$ \\
\hline Routinely every visit & 27.3 & 28.4 \\
Once a year & 11.2 & 12.8 \\
$\begin{array}{l}\text { Only if I complain of a } \\
\text { problem at a site }\end{array}$ & 25.5 & 19.6 \\
$\begin{array}{l}\text { I can't remember my sites ever } \\
\text { being checked }\end{array}$ & 36.0 & 39.2 \\
\hline
\end{tabular}

Table 11 Last time patient given instructions or advice on injections

\begin{tabular}{lll}
\hline Frequency & $\begin{array}{l}\text { \% Turkey } \\
\boldsymbol{N}=\mathbf{1 3 2 6}\end{array}$ & $\begin{array}{l}\text { \% ROW } \\
\boldsymbol{N}=\mathbf{8 2 6 2}\end{array}$ \\
\hline Within the past 6 months & 49.4 & 35.4 \\
Within the past 6-12 months & 27.4 & 16.0 \\
Sometime in the last 1-5 years & 13.6 & 22.8 \\
Sometime in the last 5-10 years & 5.1 & 14.8 \\
Never & 4.5 & 10.9 \\
\hline
\end{tabular}

general nurses are less involved in diabetes management in Turkey than in ROW.

Table 10 shows how frequently injection sites are checked in Turkey by HCP and the results are very similar to ROW. Nevertheless the goal of checking injection sites at least once a year is not being met for the majority of patients. Patients were asked when they last received instruction or advice on injections. Table 11 shows that Turkey is performing considerably better than ROW in giving advice within the last year.

Turkish patients were asked to report which injection topics they could not remember ever being trained on. Table 12 shows that for most topics, a similar percentage of Turkish patients could not remember being trained as in ROW.

Table 13 shows the identity of the HCP who filled out the ITQ. Turkish diabetes nurses had 
Table 12 Topics patients cannot remember ever being trained on

\begin{tabular}{|c|c|c|}
\hline Topic & $\begin{array}{l}\% \text { Turkey } \\
N=1265\end{array}$ & $\begin{array}{l}\text { \% ROW } \\
N=8790\end{array}$ \\
\hline $\begin{array}{l}\text { Injection sites (e.g., thigh, arm, } \\
\text { buttock, abdomen) }\end{array}$ & 12.8 & 11.6 \\
\hline $\begin{array}{l}\text { Skin thickness and appropriate } \\
\text { depth of injection }\end{array}$ & 21.7 & 27.2 \\
\hline Length of needle & 24.4 & 25.6 \\
\hline $\begin{array}{l}\text { How to do a skin lift or "pinch } \\
\text { up" the skin }\end{array}$ & 20.7 & 18.2 \\
\hline $\begin{array}{l}\text { How long to hold a skin lift or } \\
\text { "pinch up" }\end{array}$ & 23.9 & 25.7 \\
\hline Angle of needle entry & 11.2 & 16.1 \\
\hline $\begin{array}{l}\text { How long to keep the needle in } \\
\text { the skin after injection }\end{array}$ & 13.1 & 16.4 \\
\hline Rotating within an injection site & 22.3 & 18.4 \\
\hline $\begin{array}{l}\text { Prevention of air bubbles } \\
\text { (syringe) or proper priming of } \\
\text { pen needle }\end{array}$ & 23.1 & 19.7 \\
\hline $\begin{array}{l}\text { Mixing insulin in a syringe (for } \\
\text { syringe users) }\end{array}$ & 25.2 & 30.3 \\
\hline Re-suspension of cloudy insulin & 24.0 & 25.0 \\
\hline Single use of pen needle/syringe & 13.1 & 19.0 \\
\hline $\begin{array}{l}\text { Safe disposal of sharps (pen } \\
\text { needles, syringes) }\end{array}$ & 37.5 & 28.2 \\
\hline
\end{tabular}

Table 13 Professional who filled out the ITQ

\begin{tabular}{lcl}
\hline Professional & $\begin{array}{c}\text { \% Turkey } \\
\boldsymbol{N}=\mathbf{1 5 0}\end{array}$ & $\begin{array}{l}\text { \% ROW } \\
\boldsymbol{N}=\mathbf{1 1 1 3}\end{array}$ \\
\hline General nurse & 9.3 & 18.1 \\
Diabetes nurse & 88.7 & 51.7 \\
Diabetes educator & 2.0 & 25.6 \\
Doctor (general practitioner) & 0.0 & 1.2 \\
Doctor (specialist) & 0.0 & 3.4 \\
\hline
\end{tabular}

the highest percentage, higher than in ROW. Most Turkish HCP (89.9\% or 133 of 148) knew about the new injection recommendations [5] and almost all had changed their practice as a consequence.

\section{DISCUSSION}

Injecting insulin is not without its risks [6]. These include intramuscular (IM) or intradermal (ID) injections, which often distort the pharmacokinetics (PK) and pharmacodynamics (PD) of insulin and may lead to adverse effects on glucose control; injection pain, bruising, bleeding; leakage of insulin from injection sites or the device itself; and LH. The last of these is probably the most common serious complication of incorrect injection technique, even though others often get more attention than LH [7].

LH has been the subject of considerable recent research. These lesions had largely been ignored or unknown prior to recent studies. It takes considerable skill and training before HCP can reliably diagnose LH. For example HCP should use specific palpation techniques and should learn the value of performing a skin lift or pinch for diagnosis of LH. They should understand how to compare inelastic skin to soft, elastic and easily liftable skin [8]. They should also be trained in the use of gels to achieve better lubrication and enhanced sensitivity of the fingers for detecting $\mathrm{LH}$.

The better the HCP is trained at using these techniques the higher the prevalence of $\mathrm{LH}$ detected. The fact that LH is frequent (present in up to $2 / 3 \mathrm{~s}$ of injectors in one recent study [9]), that patients and HCP are in many cases unaware of its existence, and that patients often continue to inject into it-sometimes consciously, most often unwittingly-have come as an unwelcome surprise to the diabetes community.

In an earlier study in Turkey, Vardar and Kizilci [10] found LH in $48.8 \%$ of 215 insulininjecting patients. By logistic regression analysis, they were able to identify three independent risk factors for LH: long-term insulin use $(p=0.001)$; failure to carefully rotate injection sites $(p=0.004)$; and the reuse of insulin needles $(p=0.004)$. Two other studies $[9,11]$ support these as the main risk factors for $\mathrm{LH}$. 
Our survey found that nearly one-third of Turkish insulin users described lesions consistent with LH at their injection sites and that an almost equal percentage were found to have $\mathrm{LH}$ by the examining nurse (using visual inspection and palpation). These values are consistent with those found in ROW but are lower than those in many studies in which nurses had been carefully trained to look for LH $[9,12-15]$. The ITQ was performed in Turkish centers with dedicated diabetes nurses. However in Turkey there are only about 500 such nurses for the 7 million diabetic patients. Hence not all insulin injectors have the opportunity to receive training from them. This means that the true prevalence of $\mathrm{LH}$ could be considerably higher than what we found. In fact the Turkish values for LH found in the 2009 ITQ [16] are even lower than those found in 2015 (Table 14), possibly because nurses in earlier years were even less trained to look for LH than they are now.

Hence we may be fairly sure that a third of current Turkish insulin-using patients have LH at one or another of their injection sites (Tables 1,2) and over half of these continue to inject into it at least daily (Table 4). Reasons for doing this are similar in Turkey as in ROW: convenience, habit, and pain-avoidance (Table 5). Turkish nurses who examined injection sites found more LH by palpation than they did visually (Table 2), a pattern that holds also in ROW. This points to the importance of examining sites carefully using both the eyes and hands. Nurses should lubricate their hands with gel before the exam and use an undulating, circular motion, similar to the one used to examine the breast. Table 3 shows that LH lesions in Turkey average about $35 \mathrm{~mm}$ $(3.5 \mathrm{~cm})$, a dimension easy enough to detect, once one begins to look for them.

Almost all studies of patients injecting into LH show insulin absorption to be unpredictable and/or delayed, often leading to poor glucose control [17-21]. In the best one of these studies, glucose clamps were used in patients with LH [22] to assess PK and PD when insulin was injected into LH compared to normal tissue. Results showed that PK is substantially blunted in LH injections and PD is much more variable compared to injections into normal
Table 14 Comparison of previous Turkish ones (2009) with latest Turkish ITQ results (2015)

\begin{tabular}{|c|c|c|}
\hline Parameter & 2009 & 2015 \\
\hline Number of participants & 597 & 1376 \\
\hline Number of participating centers & 18 & 56 \\
\hline Age of participants (mean in years) & 48.1 & 45.0 \\
\hline Duration of therapy (mean in years) & 6.9 & 6.9 \\
\hline BMI of participants $\left(\mathrm{kg} / \mathrm{m}^{2}\right.$, mean $)$ & 28.3 & 28.5 \\
\hline HbAlc (\%, mean) & 8.2 & 9.1 \\
\hline Participants using insulin pen & $98.3 \%$ & $98.1 \%$ \\
\hline Participants using $8 \mathrm{~mm}$ needle & $83.5 \%$ & $34.7 \%$ \\
\hline Participants using needle $>8 \mathrm{~mm}$ & $5.3 \%$ & $0.9 \%$ \\
\hline Participants using needle $<8 \mathrm{~mm}$ & $11.2 \%$ & $64.4 \%$ \\
\hline Participants injecting into abdomen ${ }^{a}$ & $88.9 \%$ & $86.5 \%$ \\
\hline Participants injecting into thigh $^{\mathrm{a}}$ & $75.5 \%$ & $80.1 \%$ \\
\hline Participants injecting into buttocks ${ }^{\mathrm{a}}$ & $10.8 \%$ & $20.5 \%$ \\
\hline Participants injecting into arm $^{a}$ & $66.7 \%$ & $84.2 \%$ \\
\hline Participants injecting using pinch up & $87.7 \%$ & $52.3 \%$ \\
\hline Rotation of injection sites & $89.7 \%$ & $90.2 \%$ \\
\hline $\begin{array}{l}\text { Prevalence of occasional bleeding or } \\
\text { bruising }\end{array}$ & $81.4 \%$ & $60.2 \%$ \\
\hline Prevalence of patient-reported LH & $31.1 \%$ & $31.2 \%$ \\
\hline Prevalence of nurse-discovered LH & $21.8 \%$ & $27.4 \%$ \\
\hline Participants who reuse pen needles & $44.2 \%$ & $24.2 \%$ \\
\hline $\begin{array}{l}\text { Injections sites checked on every office } \\
\text { visit }\end{array}$ & $18.8 \%$ & $27.3 \%$ \\
\hline Needles disposed into rubbish directly & $80.8 \%$ & $70.0 \%$ \\
\hline Disposal into rubbish without recapping & $8.6 \%$ & $5.8 \%$ \\
\hline
\end{tabular}

a Percentages add to over 100 because patients use multiple sites

tissue. A mixed meal study in the same patient population confirmed the slower PK and decreased PD of insulin when LH injections are compared with those into normal tissue, with much greater glucose excursions post-meal in the former case. 
More than a quarter of Turkish patients have frequent unexplained hypoglycemia and nearly 2 out of 5 have glycemic variability (Table 6), both of which have been linked to the presence of LH and the habit of injecting into it [3]. Therefore, Turkish patients with LH should be instructed to stop injecting into LH and move to healthy sites without LH. Once patients begin injecting in these new sites they will need to reduce their insulin dose, likely by up to $20 \%$. HCP should instruct patients to reduce doses immediately, starting with the first injection into non-LH tissue. Insulin injected into the new sites has a normal PK and PD and if patients continue with their usual doses this will almost always result in hypoglycemia.

Injections should be rotated so that new injections are always given in a different site (at least $1 \mathrm{~cm}$ ) from previous ones. Patients should also refrain from reusing needles, since used needles may cause more tissue trauma and increase the risk for LH. Turkish patients without LH should be instructed to carefully follow the rotation and reuse advice above in order to avoid LH in the future. Several studies have shown that the surest way to keep tissue healthy is to consistently rotate injection sites as described above [23-25]. We found that Turkish patients who did rotate sites were largely following this $1-\mathrm{cm}$ rule already (Table 8 ).

Education seems to work when it comes to LH. In a multicenter interventional study in the UK [26] an educational approach focused on the above recommendations (rotating sites, using 4-mm needles, and no reuse) resulted in significantly lower clinically detectable LH levels after 6 months. LH either disappeared completely or decreased by approximately half its original size. The average HbA1c decreased by more than $4 \mathrm{mmol} / \mathrm{L}$ (approximately $0.5 \%$ ) and there were significantly lower levels of unexplained hypoglycemia and glucose variability. The mean TDD decreased by 5.6 IU by study end.

In a prospective, controlled, multicenter study in France, in which all patients had LH [27], an intervention similar to that in the UK study led to a significant decrease of TDD (5 IU vs baseline, $p=0.035)$, decreases in HbA1c (mean fall of $0.5 \%$ ), and significant improvement in injection technique habits after
6 months. In a recently published study in Russia [28] patients who received interventions similar to the above had HbA1c falls of approximately $1 \%$ in a similar time period.

In the Turkish study, as with ROW, we did not find that key injection parameters (e.g., correct rotation, avoidance of $\mathrm{LH}$, appropriate needle length, correct use of skin folds, single use of needles, safe sharps disposal) were better or worse as a function of duration of insulin therapy. Patients who have been injecting insulin for years often have engrained errors in technique and need the same training and education as newer-to-insulin patients.

In Turkey the diabetes nurse has by far the largest role in teaching patients how to inject. Nearly $40 \%$ of Turkish injectors get their sites checked at least annually, and a larger proportion than ROW had received recent (within the last 12 months) instruction on how to inject properly. Unfortunately the optimal timing for inspection of injection sites for LH and other complications has not yet been established by clinical studies. Similarly, the optimal timing for giving injection training is still unstudied. Nevertheless the new insulin delivery recommendations elaborate strategies for both based on experience and consensus opinion [5]. More than $60 \%$ of Turkish patients reported that they can not remember their sites ever being checked or only get them checked if they complained. This clearly indicates that we still need to focus on appropriate injection techniques in the country.

Table 14 compares the ITQ results from 2009 with those of 2015 for certain key parameters. The two study populations were not the same and the questionnaires were slightly different, but there was sufficient overlap to justify our comparison. It is clear that there has been a dramatic "shift to short" in terms of needle length. With this shift, fewer patients are pinching up the skin; in fact with the shortest (4 $\mathrm{mm})$ needle this is no longer needed, except in very select populations. Bleeding and bruising are also down. Several other encouraging signs are seen: pen needle reuse is less frequent, more patients are having their injection sites checked at each office visit, and disposal of used sharps is somewhat better. However HbA1c is 
higher in our most recent study, for unknown reasons. For most other parameters, including body mass index (BMI), injection sites used, and $\mathrm{LH}$, the values are essentially unchanged.

\section{Limitations}

Like all broad surveys that aim to be representative, the ITQ cast a wide net for both patients and HCP. Our patient population included a spectrum of patients from those who had had best-in-class training for injection technique to those who reported getting no injection training at all. Most, however, fell somewhere in between. Consequently the patient injection practices we report on here span from optimal to the clearly substandard and even dangerous. Similarly, the injection technique expertise of HCP varied widely as well. It was, for example, impossible to train all HCP to the same level of expertise in the diagnosis of LH. Recent studies have shown that flat or non-palpable $\mathrm{LH}$ requires a much higher level of expertise to diagnose than visible or easily palpable LH. Flat or non-visible LH can be identified by pinching the skin where the presence of LH is suspected and comparing the thickness of the skin fold with nearby normal areas $[29,30]$. It is probable that we included HCP who might be proficient at diagnosing easily detected lesions, but not the more subtle ones. This might account for the relatively low percentages of $\mathrm{LH}$ detected compared to findings in other published studies where HCP were carefully trained in LH detection. However, we believe this broad approach, though limiting our study in some respects, best reflects the real world of injection practice in Turkey and ROW.

\section{CONCLUSIONS}

In summary, Turkish patients and professionals have clearly made progress in injection technique, but there are still considerable challenges ahead which the new injection techniques and treatment guideline for health care professionals will help address. This study provides a basis for improving the injection site examination in general clinical practice and also creating protocols for detecting and preventing LH in Turkey. The authors plan to conduct another ITQ approximately 1 year after these guidelines are published in order to assess their impact on Turkish injection practice.

\section{ACKNOWLEDGEMENTS}

Our sincerest thanks go to the 1376 patients in the 56 participating centres along with their doctors and nurses and patients (see Appendix Table 15 for all names of HCP).

Funding. BD Diabetes Care sponsored this study by reimbursing hospitals for time spent. They also funded the article processing charges for this article. No healthcare professional or patient received payment for participating in the study and no payments were given to any author for publication of this article. All authors had full access to all of the data in this study and take complete responsibility for the integrity of the data and accuracy of the data analysis.

Authorship. All named authors meet the International Committee of Medical Journal Editors (ICMJE) criteria for authorship for this manuscript, take responsibility for the integrity of the work as a whole, and have given final approval to the version to be published.

Prior Publications. This article is another in a series of country-specific analyses of the worldwide ITQ survey results. Two previous publications appeared in an issue of this journal in 2017 entitled "Indian injection technique study: population characteristics and injection practice" [31] and "Indian injection technique study: injecting complications, education, and the health care professional" [4], both from volume 8 .

Disclosures. Cansu Aslan is an employee of $\mathrm{BD}$, a manufacturer of injecting devices. Laurence $\mathrm{J}$. Hirsch is an employee of $\mathrm{BD}$, a manufacturer of injecting devices. Kenneth W. Strauss is an employee of BD, a manufacturer of injecting devices. All other authors (Selcuk 
Dagdelen, Oguzhan Deyneli, Nermin Olgun, Zeynep Osar Siva, Mehmet Sargin, Sükrü Hatun, Mustafa Kulaksizoglu and Ahmet Kaya) have nothing to disclose.

Compliance with Ethics Guidelines. All procedures performed in studies involving human participants were in accordance with the ethical standards of the institutional and/or national research committee and with the 1964 Helsinki declaration and its later amendments or comparable ethical standards. Informed consent was obtained from all individual participants included in the study. No participant identifying information was made available to the sponsor and participants were informed that their care would not be affected in any way by their participation. They were not put at risk in any way by the study and were not paid to participate. Ethics committee approval was therefore not generally required but was obtained whenever specifically requested by a center and/or by local regulations. All 56 participating centers from 29 cities in Turkey (as in rest of world, ROW) did so willingly and without financial incentive.
Data Availability. Worldwide as well as country-specific ITQ survey data (including Turkey) are available at Tableau Public Adam Young's Profile website, http://tabsoft.co/ 23V6ofi. This database contains all the raw ITQ data, both for Turkey and ROW (by individual country), and allows the user to select and view results for specific parameters or combinations of parameters. This site allows the generation of all datasets used in the current study.

Open Access. This article is distributed under the terms of the Creative Commons Attribution-NonCommercial 4.0 International License (http://creativecommons.org/licenses/ by-nc/4.0/), which permits any noncommercial use, distribution, and reproduction in any medium, provided you give appropriate credit to the original author(s) and the source, provide a link to the Creative Commons license, and indicate if changes were made.

\section{APPENDIX}

Table 15 Health care professionals who participated in this study

\begin{tabular}{llll}
\hline City & Center & Name of diabetes nurse & Patients \\
\hline Adana & Cukurova Universitesi Tip Fakultesi Balcali Hastanesi & AYFER BAHTIYAR \\
& & GÜLCAN DELIDAĞ (Pediatric \\
& & Diabetes Nurse) \\
Afyon & Afyon Kocatepe Universitesi Hastanesi & NUR ŞERİF KARADEMİR & 31 \\
& & SONGÜL UÇAR \\
Amasya & Sabuncuoglu Serefeddin Egitim ve Arastirma Hastanesi & ÇAĞLA DEMİR \\
Ankara & Ankara Ataturk Egitim Ve Arastirma Hastanesi & BİRGÜL GENÇ \\
Ankara & SBU Ankara Dr. Sami Ulus Kadin Dogum Cocuk Sagligil ve & NURDAN YILDIRIM (Pediatric & 37 \\
& Hastaliklari Egitim Ve Arastirma Hastanesi & Diabetes Nurse) & 25 \\
Ankara & Hacettepe Universitesi Hastanesi & AYŞE İLHAN & 32 \\
Ankara & Hacettepe Universitesi Ihsan Dogramaci Cocuk Hastanesi & SERPİL ÇAKMAK (Pediatric & 21 \\
& & Diabetes Nurse) &
\end{tabular}


Table 15 continued

\begin{tabular}{|c|c|c|c|}
\hline City & Center & Name of diabetes nurse & Patients \\
\hline Ankara & Ozel Bayindir Hastanesi & $\begin{array}{l}\text { SEVILAY SUNGUR } \\
\text { YURDAKUL } \\
\text { HANIFE AKMAN } \\
\text { NERIMAN TARHAN }\end{array}$ & 35 \\
\hline Ankara & Diskapi Yildirim Beyazit Egitim Ve Arastirma Hastanesi & FATMA GÖROĞLU & 25 \\
\hline Antalya & Akdeniz Universitesi Hastanesi & ŞEFIKA DALKIRAN & 25 \\
\hline Denizli & Denizli Devlet Hastanesi & $\begin{array}{l}\text { HAFİZE KANYILMAZ } \\
\text { GÖKÇE GÖKÇE }\end{array}$ & 29 \\
\hline Antalya & $\begin{array}{l}\text { Saglik Bilimleri Universitesi Antalya Egitim ve Arastirma } \\
\text { Hastanesi }\end{array}$ & $\begin{array}{l}\text { AYFER UMAY } \\
\text { AYSUN ÜNAL } \\
\text { SEHER DEMİ }\end{array}$ & 6 \\
\hline Balikesir & Ayvalik Devlet Hastanesi & SEVGİ DUMAN & 18 \\
\hline Balikesir & Devlet Hastanesi & RABİA CEYLAN SALI & 25 \\
\hline Bolu & Abant Izzet Baysal Universitesi Tip Fakultesi Hastanesi & SATI CAN & 25 \\
\hline Bursa & SBU Bursa Yuksek Ihtisas Egitim Arastirma Hastanesi & SİBEL YAVAŞ & 19 \\
\hline Bursa & Uludag Universitesi Saglik Uygulama Ve Arastima Hastanesi & GÜLSEV DİRİK & 33 \\
\hline Bursa & Bursa Yenisehir Devlet Hastanesi & İLDA EROL & 25 \\
\hline Çanakkale & Canakkale Devlet Hastanesi & HACER KARABULUT & 16 \\
\hline Diyarbakir & Diyarbakır Cocuk Hastaliklari Hastanesi & MÜLKİYE AYDIN & 25 \\
\hline Düzce & Ataturk Devlet Hastanesi & İLKAY BAYRAM & 31 \\
\hline Edirne & Trakya Universitesi Saglik Araştırma ve Uygulama Merkezi & $\begin{array}{l}\text { ÖZLEM COŞAR ÜNAL } \\
\text { BURCU KESKIN (Pediatric } \\
\text { Diabetes Nurse) }\end{array}$ & 31 \\
\hline Erzurum & $\begin{array}{l}\text { Ataturk Universitesi Arastirma Hastanesi/Ataturk Universitesi } \\
\text { Saglik Arastirma ve Uygulama Merkezi }\end{array}$ & $\begin{array}{l}\text { SEVİÇ DAKAK } \\
\text { SERPİL ÜÇPINAR }\end{array}$ & 7 \\
\hline Eskiş ehir & Acibadem Eskisehir Hastanesi & AYFER AKTAŞ & 23 \\
\hline Eskiş ehir & $\begin{array}{l}\text { Eskisehir Osmangazi Universitesi Saglık Arastirma ve Uygulama } \\
\text { Hastanesi }\end{array}$ & $\begin{array}{l}\text { KEVSER KARAOĞLU } \\
\text { SADIFE KARATEPE } \\
\text { SEVIYYE MAHMUTOĞLU } \\
\text { INAN }\end{array}$ & 26 \\
\hline Giresun & $\begin{array}{l}\text { GIRESUN UNIVERSITEII PROF. DR. A. ILHAN OZDEMİ } \\
\text { EGITIM ARASTIRMA HASTANESI }\end{array}$ & MEDİHA DÖNMEZ KURT & 5 \\
\hline
\end{tabular}


Table 15 continued

\begin{tabular}{|c|c|c|c|}
\hline City & Center & Name of diabetes nurse & Patients \\
\hline İstanbul & Kadikoy/Kozyatagi Acibadem Hastaneleri & $\begin{array}{l}\text { GÜLİN ÇEVİK } \\
\text { ÖZNUR YÜCE } \\
\text { YASEMİN KANEK }\end{array}$ & 11 \\
\hline İstanbul & $\begin{array}{l}\text { Istanbul Sagllk Bilimleri Universitesi Kanuni Sultan Suleyman } \\
\text { Egitim ve Arastirma Hastanesi }\end{array}$ & GÜLDEN ANATACI & 6 \\
\hline İstanbul & $\begin{array}{l}\text { Marmara Universitesi Istanbul Pendik Egitim ve Araştırma } \\
\text { Hastanesi }\end{array}$ & SERPIL ESMEN & 25 \\
\hline İstanbul & Bagcilar Egitim Ve Arastirma Hastanesi & SULTAN YURTSEVER & 30 \\
\hline İstanbul & Istanbul Universitesi Cerrahpaşa Tip Fakultesi Hastanesi & $\begin{array}{l}\text { ŞENAY ZUHUR } \\
\text { TÜLAY TOKGÖZ ŞİMŞEK }\end{array}$ & 25 \\
\hline İstanbul & Haseki Egitim Ve Arastirma Hastanesi & EMINE YILMAZLAR & 30 \\
\hline İstanbul & Istanbul Universitesi İstanbul Tip Fakultesi Hastanesi & $\begin{array}{l}\text { SELDA ÇELİK } \\
\text { SALİHA YILMAZ (Pediatric } \\
\text { Diabetes Nurse) }\end{array}$ & 24 \\
\hline İstanbul & Istanbul Kartal Dr. Lutfi Kirdar Egitim ve Arastirma Hastanesi & ŞENGÜL IŞIK & 25 \\
\hline İstanbul & Pendik Kaynarca Semt Poliklinigi Diyabet Merkezi & $\begin{array}{l}\text { GÜL İPEK YANILMAZ } \\
\text { GÖNÜL ERKUT }\end{array}$ & 32 \\
\hline İstanbul & Medeniyet Universitesi Goztepe Egitim Ve Arastirma Hastanesi & $\begin{array}{l}\text { DERYA KARAMAN } \\
\text { NURDAN YÖRÜK }\end{array}$ & 26 \\
\hline İstanbul & Istanbul Sisli Hamidiye Etfal Egitim ve Arastirma Hastanesi & GÜLBAHAR POLAT & 25 \\
\hline İstanbul & Umraniye Egitim Ve Arastirma Hastanesi & ZEKİYE ÇELİKÖZ & 28 \\
\hline İzmir & Dokuz Eylul Universitesi Arastirma Uygulama Hastanesi & $\begin{array}{l}\text { HATİCE TEKELİ ASLAN } \\
\text { (Pediatric Diabetes Nurse) } \\
\text { BELGİN BEKTAŞ }\end{array}$ & 26 \\
\hline İzmir & Ege Universitesi Tip Fakultesi Hastanesi & $\begin{array}{l}\text { YILDIZ ÖZBEY } \\
\text { NURAN HOROZOĞLU } \\
\text { GÜNAY DEMİR (Pediatric } \\
\text { Diabetes Nurse) }\end{array}$ & 31 \\
\hline Kayseri & Erciyes Universitesi Tip Fakultesi Hastanesi & $\begin{array}{l}\text { SACİDE KILIÇ } \\
\text { NURTEN VARIYYENLİ } \\
\quad \text { (Pediatric Diabetes Nurse) }\end{array}$ & 25 \\
\hline Kayseri & $\begin{array}{l}\text { Saglik Bilimleri Universitesi Kayseri Egitim Ve Arastirma } \\
\text { Hastanesi }\end{array}$ & HAYRIYE TOPRAK BEYAZ & 36 \\
\hline Kocaeli & Kocaeli Devlet Hastanesi & ALIME KARATAŞ & 25 \\
\hline
\end{tabular}


Table 15 continued

\begin{tabular}{|c|c|c|c|}
\hline City & Center & Name of diabetes nurse & Patients \\
\hline Kocaeli & Kocaeli Universitesi Arastirma ve Uygulama Hastanesi & $\begin{array}{l}\text { YASEMIN ERKEK } \\
\text { YELIZ ERDEM } \\
\text { SEVGİ AKSOY AKBEL } \\
\text { (Pediatric Diabetes Nurse) } \\
\text { EBRU ERCANLI (Pediatric } \\
\text { Diabetes Nurse) }\end{array}$ & 25 \\
\hline Konya & Konya Egitim Ve Arastirma Hastanesi & FATOŞ ERDAĞI & 25 \\
\hline Konya & Necmettin Erbakan Universite Hastanesi Meram Tip Fakultesi & FATMA ÖZDAMAR & 29 \\
\hline Malatya & Malatya Egitim Arastirma Hastanesi & MELEK YILDIRIM & 7 \\
\hline Mersin & Mersin Toros Devlet Hastanesi & RABİYA DÖLEK & 25 \\
\hline Mersin & Mersin Universitesi Saglık Arastirma ve Uygulama Hastanesi & EYLEM TÜRK & 31 \\
\hline Ordu & Ordu Devlet Hastanesi & CANDEĞER UZUNLAR & 30 \\
\hline Samsun & Ondokuz Mayis Universitesi Tip Fakultesi Hastanesi & $\begin{array}{l}\text { GÖNÜL GÜVELİ (Pediatric } \\
\text { Diabetes Nurse) } \\
\text { GÜLAY BAYRAK }\end{array}$ & 25 \\
\hline Sivas & Cumhuriyet Universitesi Arastirma ve Uygulama Hastanesi & ZEHRA ÇELIK & 36 \\
\hline Sivas & Sivas Numune Hastanesi & RABİA AKÇA & 26 \\
\hline Tekirdağ & Tekirdag Devlet Hastanesi & SERAP MAVİLI & 30 \\
\hline Trabzon & $\begin{array}{l}\text { Karadeniz Teknik Universitesi Saglik Uygulama Arastirma } \\
\text { Merkezi Farabi Hastanesi }\end{array}$ & $\begin{array}{l}\text { NILGÜN } \\
\text { ÇATALAHMETOĞLU }\end{array}$ & 25 \\
\hline Zonguldak & $\begin{array}{l}\text { Bulent Ecevit Universitesi Saglik Uygulama ve Arastirma } \\
\text { Hastanesi }\end{array}$ & $\begin{array}{l}\text { SAFIYYE KÖKDEN } \\
\text { ÇATALÇAM }\end{array}$ & 32 \\
\hline
\end{tabular}

\section{REFERENCES}

1. Dagdelen S, Deyneli O, Olgun N, et al. Turkish insulin injection technique study: population characteristics of Turkish patients with diabetes who inject insulin and details of their injection practices as assessed by survey questionnaire. Diabetes Ther. 2018. (In press).

2. Frid $\mathrm{AH}$ et al. Worldwide injection technique questionnairestudy: population parameters and injection practices. Mayo Clin Proc. 2016;91(9):1212-1223.

3. Frid $\mathrm{AH}$ et al. Worldwide injection techniquequestionnaire study: injecting complications and role of the professional. Mayo Clin Proc. 2016;91(9):1224-1230.
4. Kalra S, Mithal A, Sahay R, et al. Indian injection technique study: injecting complications, education, and the health care professional. Diabetes Ther. 2017;8(3):659-72. https://doi.org/10.1007/ s13300-017-0244-9.

5. Frid AH et al. New insulin delivery recommendations. Mayo Clin Proc. 2016;91(9):1231-1255.

6. Gentile S, Agrusta M, Guarino G, et al. Metabolic consequences of incorrect insulin administration techniques in aging subjects with diabetes. Acta Diabetol. 2011;48(2):121-5. https://doi.org/10. 1007/s00592-009-0172-x.

7. Gentile S, Strollo F, Della Corte T, Marino G, Guarino G. Insulin related lipodystrophic lesions and hypoglycemia: double standards? Diabetes 
Metab Syndr. 2018. https://doi.org/10.1016/j.dsx. 2018.04.023.

8. Gentile S, Strollo F, De Rosa N, et al. Injection-related local side effects in the treatment of diabetes mellitus: a methodological approach and possible solutions in the consensus statement of the AMDOSDI study group on injection technique. In: Diabetic complications. SMGroup, Dover. http://www. smgebooks.com/diabetic-complications/chapters/ DC-16-04.pdf. Accessed 12 May 2018.

9. Blanco M, Hernández MT, Strauss KW, Amaya M. Prevalence and risk factors of lipohypertrophy in insulin-injecting patients with diabetes. Diabetes Metab. 2013;39(5):445-53.

10. Vardar B, Kizilci S. Incidence of lipohypertrophy in diabetic patients and a study of influencing factors. Diabetes Res Clin Pract. 2007;77:231-6.

11. Saez-de Ibarra L, Gallego F. Factors related to lipohypertrophy in insulin-treated diabetic patients; role of educational intervention. Pract Diab Int. 1998;15:9-11.

12. Partanen TM, Rissanen A. Insulin injection practices. Pract Diab Int. 2000;17:252-4.

13. Kordonouri O, Lauterborn R, Deiss D. Lipohypertrophy in young patients with type 1 diabetes. Diabetes Care. 2002;25(3):634.

14. Grassi G, Scuntero P, Trepiccioni R, et al. Optimizing insulin injection technique and its effect on blood glucose control. J Clin Transl Endocrinol 1(2014):145-150.

15. Ji L, Li Q, Wei G. Lipohypertrophy-prevalence, risk factors and clinical characteristics of insulinrequiring patients in China. Abstract, EASD Vienna 2014, Tracking Number: A-14-747.

16. De Coninck C, Frid A, Gaspar R, et al. Results and analysis of the 2008-2009 insulin injection technique questionnaire survey. J Diabetes. 2010;2(3):168-79.

17. Young RJ, Hannan WJ, Frier BM, Steel JM, Duncan LJ. Diabetic lipohypertrophy delays insulin absorption. Diabetes Care. 1984;7:479-80.

18. Chowdhury TA, Escudier V. Poor glycaemic control caused by insulin induced lipohypertrophy. Brit Med J. 2003;327:383-4.

19. Johansson UB. Impaired absorption of insulin aspart from lipohypertrophic injection sites. Diabetes Care. 2005;28:2025-7.

20. Frid A, Linden B. Computed tomography of injection sites in patients with diabetes mellitus.
Injection and absorption of insulin. Stockholm: Thesis. 1992.

21. Gentile S, Strollo F, Corte TD, Marino G, Guarino G, Italian Study Group on Injection Techniques. Skin complications of insulin injections: a case presentation and a possible explanation of hypoglycaemia. Diabetes Res Clin Pract. 2018;138:284-7. https://doi.org/10.1016/j.diabres.2018.02.005.

22. Famulla S, Hövelmann U, Fische A, et al. Insulin injection into lipohypertrophic tissue: blunted and more variable insulin absorption and action and impaired postprandial glucose control. Diabetes Care. 2016;39:1486-92. https://doi.org/10.2337/ dc16-0610.

23. Ahern J, Mazur ML. Site rotation. Diabetes Forecast. 2001;54:66-8.

24. Bantle JP, Weber MS, Rao SM, Chattopadhyay MK, Robertson RP. Rotation of the anatomic regions used for insulin injections day-to-day variability of plasma glucose in type 1 diabetic subjects. JAMA. 1990;263:1802-6.

25. Davis ED, Chesnaky P. Site rotation...taking insulin. Diabetes Forecast. 1992;45:54-6.

26. Smith M, Clapham L, Strauss K. UK lipohypertrophy intervention study. Diabetes Res Clin Pract. 2017;126:248-53.

27. Campinos $\mathrm{C}$, et al. An effective intervention for diabetic lipohypertrophy: results of a randomised, controlled, prospective, multicenter study in France. Diabetes Technol Ther. 2017;19:623-32.

28. Misnikova I, Gubkina V, Lakeeva T, Dreval A. A randomized controlled trial to assess the impact of proper insulin injection technique training on glycemic control. Diabetes Ther. 2017;8(6):1309-18. https://doi.org/10.1007/s13300-017-0315-y.

29. Gentile S, Guarino G, Giancaterini A, Guida P, Strollo F, AMD-OSDI Italian Injection Technique Study Group. A suitable palpation technique allows to identify skin lipohypertrophic lesions in insulintreated people with diabetes. Springerplus. 2016;5:563. https://doi.org/10.1186/s40064-0161978-y.

30. Gentile S, Strollo F, Guarino G, et al. Factors hindering correct identification of unapparent lipohypertrophy. J Diab Metab Dis Contr. 2016;3:00065. https://doi.org/10.15406/jdmdc.2016.03.00065.

31. Kalra S, Mithal A, Sahay R, et al. Indian injection technique study: population characteristics and injection practices. Diabetes Ther. 2017;8(3):637-57. https://doi.org/10.1007/s13300017-0243-X. 